\begin{abstract}
Natalia Maria Ruman
University of Silesia

Faculty of Arts and Sciences on Education https://orcid.org/0000-0002-7127-7651
\end{abstract}

\section{Martha Finger, Stephan Sampt}

Kirchliche Pädagogische Hochschule Wien/Krems https://orcid.org/0000-0002-7512-2868 https://orcid.org/0000-0002-6512-5897

\section{Zdenek Mruzek}

Albrechtova Střední Škola in Český Těšín https://orcid.org/0000-0001-7015-867X

\title{
The Role of Information Technology in Ecological Education in the Context of Cooperation between High Schools from Poland, Austria and the Czech Republic
}

\begin{abstract}
Contemporary ecological problems of the world can not only be studied as a survey of knowledge, opinions and attitudes, but also as a project designed to stimulate society from an early age towards responsibility for the environment and to increase individual ecological awareness. The article is a summary of the work carried out during the project of three cooperating schools representing Poland, Austria and the Czech Republic. The aim of the project was to consider the importance of ecology at the level of participating secondary schools in selected countries and the use of technology to implement this project. International project coordinators were interviewed. The questions concerned: application of technology in an international school project, summary of the effects of the Polish school's cooperation
\end{abstract}


with foreign schools and new challenges in the digital school. A qualitative study was carried out. The project was also analyzed in terms of activities included, and the effects were presented. The main issue raised in the project is environmental protection and ecology. Attention was paid to the problems of the Earth, the common home of all people. The role of education in shaping a possible international dialogue on cooperation in the field of ecology was also emphasized. Real environmental protection, as the activities of school students from three countries described in the article show, is a new style of education, a new approach to ecology, which is a call to the right relationship of man to the world around him.

K e y w ord s: environmental protection, sustainable development, educational innovations, ecology, information technology

From the beginning of the human race, there has been a mutual interaction between man and nature. In the distant past, all the damage caused to the environment by human activities was local and the nature itself was able to compensate for it. Currently, human intervention which introduces harmful changes in the environment, is so intense that a worldwide ecological crisis has been created - a crisis which everybody should be aware of. Ecological awareness is identified with beliefs about reality, and its positive feature is the criticism of the anti-ecological character of the modern world (Sobczyk, 2003, pp. 19-21).

The competences belonging to the ecological imagination undoubtedly include three skills: prediction of the ecological effects of the actions undertaken, the ability to see and integrate the connections between human and natural processes and designing activities with the requirements of ecological knowledge (MarekBieniasz, 2004, pp. 17-19).

Ecological education means creating conditions, transferring values, evoking respect and admiration for nature so that a young man subjected to this education, creating new communities and wanting to survive and protect civilization, can respect the laws of nature, can use its goods wisely and exist in balance with the biocenosis of the surrounding environment. In order to form the desired proecological attitudes in a person, it is necessary to include ecological education in the general educational process of a young person. One cannot treat individual areas of life separately and fragmentarily. If the educational system is to be effective, it must be implemented as a whole. A significant violation of the natural and climate balance can lead to a threat and, consequently, to the disappearance of human civilization. That is why formal and informal education should raise and expand the awareness of complex environmental, social and other connections, in 
The Role of Information Technology in Ecological Education in the Context of Cooperation...

which every educational institution always participates (Brożek \& Gawlik, 2011, pp. 10-33).

Schools are usually equipped with sets of teaching aids needed to implement projects and digital equipment such as laptops/computers, projectors, cameras. It is important that teachers from partner schools cooperate with each other during and after the project. To achieve this, networking meetings are held regularly, and daily contact provided by the Moodle platform. Only such material components are needed and the cost of their use is even lower than if the project were to be carried out in real terms on an exchange basis. Above all, what is necessary is willingness. Three Schools: Poviat School Complex No. 2 in Pszczyna, Albrechtova Stredni Szkoła in Český Těšín and Bundesrealgymnasium Purkersdorf in Austria jointly carried out projects which were supported by technologies. The Poviat School Complex No. 2 in Pszczyna conducted many stationary activities for the benefit of ecology, therefore it was the leading partner in this project (Ruman, 2018, pp. 110-117).

In the 2018/2019 school year, a project was carried out between selected secondary schools in three countries: Poland, Austria and the Czech Republic. 17 students participated from the Polish school, 11 students from the Austrian school, and 20 students from the school in the Czech Republic. The aim of the project was: to improve the quality of school work, develop proper relationships with peers (primarily in English), to raise awareness of the importance of ecological activities in your life, as well as to expand knowledge about the proper and reasonable use of the Internet. The project was carried out as part of additional extracurricular activities. The program of the project provided for two hours of classes per week, although sometimes the meetings took place on a significantly extended basis.

Students willingly participated in the classes, took active part in them, the attendance was very high. They showed creative attitude, inquisitiveness and perseverance needed to achieve the goal.

Authors conducted interviews with teachers from three schools who coordinated the ecological project. Regardless of the group's characteristics (three countries - Poland, Austria and the Czech Republic), a permanent element of the project was the use of technology, which was the basis of communication. Thanks to multimedia tools, it was possible to create an interesting e-book that described intra-project activities that can serve as an inspiration for other schools or kindergartens. The e-book contains examples of scenarios of ecological meetings for children in kindergarten, ecological games with puzzles. 


\section{Background of Research and Literature Review}

Many articles have already been published on the subject of technologies used in various projects. Several are especially valuable for teachers interested in such project activities, as they may function as models or inspiration. An example is the text by Tavernise and Bertacchini, 2017. The article is devoted to designing virtual foundations for learning history, where the NetConnect project is presented on the topic of new educational strategies in the modern digital environment, which is still developing and is an important element of education at every level (Smyrnova-Trybulska et al., 2016). In schools, there are more and more innovations that, inspired by the changing demand in the work environment, force the adaptation of students' education as potential employees. To improve their education, it is also necessary to use information technologies, as shown in the article on the direction of new education in the field of fashion design, where the science of virtual prototyping using electronic textiles is shown (Han et al., 2020). Technologies primarily support learning at school (Skubała \& Smyrnova-Trybulska, 2014), also through homework, which will significantly improve reading and writing skills among high school students (Magalhães et al., 2020). An interesting study is also an article on the impact of online activities on the development of students' media competence (Simonova et al., 2017). In addition to media competences, language skills are significant abilities which a student must acquire in the education process. Language and communication skills of bi- and trilingual students and the importance of IT tools as a method of improvement are the topic of the article by three Russian authors: Guzhelya, Kurilenko and Biryukova (2019). However, the project on sustainable development in education carried out between schools in Poland and Austria can serve as an example of environmental and ecological activities (Ruman \& Kubiak, 2018).

\section{About Ecological Education - Preliminary Considerations}

The problem of nature protection has a significant social dimension. Natural resources should serve primarily to satisfy basic human needs. Both the benefits and costs of civilization and technical development should be equally distributed. You cannot charge next generations, leaving them with the heritage of devastated environment. True environmental protection is not an action aimed at completely stopping man's interference into nature and preserving it in an absolutely intact

IJREL.2020.6.2.09 p. 4/17 
The Role of Information Technology in Ecological Education in the Context of Cooperation...

state, but a harmonious coexistence and joint development of a man together with the world around him. It is, above all, a new lifestyle, solidarity between people and the resulting new attitude towards nature (Peacocke, 1991, pp. 147-149).

As long as human beings exist, there is a mutual interaction between man and nature. In past centuries, all the damage caused to the environment by human activities was local and the nature itself was able to compensate for it. Currently, human intervention, introducing harmful changes in the environment, is so intense that a worldwide ecological crisis has been created, of which everybody must be conscious from an early age. Ecological awareness is identified with beliefs about reality, and its positive feature is the criticism of the anti-ecological character of the modern world (Michalik, 2002, p. 444).

The competences belonging to the ecological imagination undoubtedly include three skills: prediction of the ecological effects of the actions undertaken, the ability to see and integrate the connections between man and natural processes and designing activities with the requirements of ecological knowledge (Papuziński, 1998, pp. 210-222).

It is known from experience that knowledge about sustainable development is not enough - this one is disseminated, and has been in the core curriculum for many years. Sustainable development would have to become a value that people will manage as well as feel responsible for strengthening. Achieving this requires systematic, consistent and careful educational activities, involving development of morality and responsibility for one's own actions and actions of others. In various areas of activities related to shaping attitudes that protect the environment, goals are set. In the area of general goals, attention is paid to the expected effects of educational activities such as:

- ecological lifestyle,

- harmonious relationship between man and nature,

- preparation to take joint actions in defense of the Earth and future generations (Kulik, 2008, p. 183).

The most important rules of ecological teaching accompanying the goals of educational activities are the principle of regularity and the principle of linking theory with practice (Sobczyk, 2003, pp. 26-28).

\section{Education for Sustainable Development}

The following definition of sustainable development applies in Polish legislation: sustainable development is a socio-economic development in which the process 
of integrating political, economic and social activities takes place, preserving the natural balance and sustainability of basic natural processes, in order to guarantee the ability to meet the basic needs of individual communities or citizens of both the modern generation and future generations (Sztumski, 2006, pp. 73-76). It is important to sensitize young people to the needs of the natural environment, to enrich their knowledge of its dependencies, to indicate the beauty and diversity of nature, to make them aware of how much depends on human beings. Knowledge about sustainable development requires systematic, consistent and careful educational activities, involving the development of morality and responsibility for their actions and others (Krzysztofiak, 2009, pp. 239-243).

However, the school has educational tasks in addition to the transfer of knowledge. Its tasks include supporting the intellectual and moral self-development of students, so that their potential creative possibilities and shaping responsibility for the state of the natural environment can be triggered. Young people should be characterized by a pro-ecological attitude, i.e. love of nature and all forms of life with a human being at the forefront. Environmental protection has real meaning only when people act according to beliefs which are deeper than those dictated by reason or market laws. The formation of the pro-environmental attitude was reflected in the record included in the International Strategy on Environmental Education: "Environmental education cannot be one more item added to the existing grid of hours. It should be included in the programs of all subjects regardless of the age of the learners [...]. Its content should penetrate into the components of school education programs" (Kowalak, 2009, pp. 313-314).

Ecological security is the state of counteracting the social consequences of the transformation of the surrounding environment. It is connected with elimination of the threats to health and life of people, which originate from the natural environment or reducing such threats to a minimum. It is a set of conditions protecting people and the environment against ecological threats and shaping natural and social relations in the Earth's biosphere, which creates proper living conditions for all humanity, without undermining the basis of life on our planet. This is achieved mainly through the implementation of innovative methods and implementation of the concept of sustainable development (Lebkowski, 2008, p. 16).

Ecological safety is a durable and continuous process aimed at achieving the desired ecological status, securing the peaceful and healthy existence of all elements of the ecosystem, using various measures consistent with the principles of internal coexistence of the state and the international community (Zacher, 1991, p. 98).

The current concept of growth is an idea based on the philosophy of sustainable development. This also applies to the transmission of cultural heritage, due to its supra-regional significance for society and the environment. Sustainable develop- 
The Role of Information Technology in Ecological Education in the Context of Cooperation...

ment is aimed at the sustainable quality of life of present and future generations, through integration and shaping the right proportions between the goals: spiritual, economic, ecological, social, institutional and spatial. The problems of the present day, such as socio-economic and cultural changes, also concern the preservation of identity and cultural heritage and should be the subject of broad scientific discussions (Piontek, 2002, p. 27).

The school development program should be oriented towards the systematic improvement of the conditions of its implementation and thus towards the development of students and the professional development of teachers whom it will create in the following years. It should meet various expectations of the local community. It is not only students and teachers who undertake many activities to improve the functioning of the school and contribute to its development, but also cooperating entities. Cooperating with local government, various institutions in the community and county, the school should invite their representatives to important ceremonies which take place and show the effects of school work visible at concerts, performances and exhibitions.

School achievements, the successes and the involvement of its pupils should be included in the local press and the Internet portals, and such activities should be treated as a form of school promotion, which is characterized by a special prosocial involvement in relation to spiritual values.

The main task of the school is to implement an educational program which promotes sustainable development, to combine ecological education of students with moral education. The school is an institution supporting development on two levels: social and individual. Social level is connected with growing in culture, taking over patterns of functioning and finding a place in the world. The individual level concerns shaping the personality, increasing self-awareness, enriching forms of self-realization. "Learner's happiness" is regarded as the goal of teaching. The teacher plays a huge role in the education process, models behaviours for students and provides them an example to follow.

Cooperation with other schools, the need for meetings of their representatives is a help and inspiration for effective implementation of education for sustainable development in schools. During such meetings, it is possible to exchange views, to reinterpret teaching content and to evaluate the methodology of teachers. These are different ways of understanding eco-development as the implementation of the global activities for sustainable development, as the improvement of education, its scientific and didactic workshop.

Partnership is characterized by interaction and communication. The educational community is a huge space for communication and meaning, in which actors - teachers, parents and children - continue to send messages through a variety 
of channels. Thanks to this, a convenient source of inspiration and development, interaction, and encounters between men are created.

Educational activities aimed at gaining experience and understanding reality, "use of living," making social changes and constant attempts to understand oneself and others create conditions for better development and creativity of students. At the same time, they enable implementing thoughtful and conscious actions, using the strength and power of authorities and values creating national and international culture.

Education for sustainable development shows its religious-ethical-philosophical dimension in starting well-thought-out and sustainable organic work at home, at the foundation, for the benefit of their own "small homeland" and their rightful citizens.

\section{Detailed Description of the Design of the Three Schools}

In this part of the article activities at the Karol Miarka County School Complex no. 2 in Pszczyna (from the School Chronicle) will be reviewed. The following are selected examples of integral ecological activities carried out in the project together with foreign schools:

- Students participated in monitoring of wild dumps. An observation was made concerning kind of waste that was found in the landfill and its quantity, and also the impact of this waste on the environment was assessed. Students wondered why landfills in wild areas are formed and what can be done to prevent people from creating them. The students of each of the partner schools completed the task in their own country and presented the results through a remote meeting.

- Students took part in the workshop "Modern methods of waste management," learned the way of waste from home to landfill and how to segregate waste. They invited a specialist from the Czech Republic who led the meeting, connecting with young people via the Internet.

- At the CHP plant, students learned where heat is coming from, how it is transported, why the pipes are cold although there is hot water flowing in them and how the heat plant differs from the CHP plant. The meeting was also held remotely, the effect was surprising, because by means of webcam, an employee at the Polish Pszczyna CHP Plant showed their place of work to curious youth, who connected via multimedia from Poland and abroad.

Together, young people also interviewed children in selected kindergartens in their surrounding area about the importance of ecology in their lives. The result of 
The Role of Information Technology in Ecological Education in the Context of Cooperation...

the analysis was surprising, because in all the studied countries children are aware of the importance of ecological activities. They believed in:

- respect for animals and plants, not trimming grass as a pro-ecological attitude;

- leading clean life through not producing pollution and too much waste;

- ecology which means eating fruit and vegetables;

- ecology which is about how to breathe fresh air and have clean water;

- ecology as life, there is no life without it.

Students from three countries also created inventions that in the future would help protect the environment. The inventions largely included technological equipment which would indicate the exact place of littering in the mountains, would give the sensor a sign that someone threw a trash bag in the forest, or indicated dripping taps loose in school and other institutions. The ideas were diverse, creative, and above all future-oriented.

These mini-projects were carried out remotely, but the effects of their implementation are valuable in the education of young people in each country participating in this project, as confirmed by the guardians.

Representatives - coordinators commented on the validity and validity of projects that are implemented using only technology as follows:

Opinion of the youth guardian from Austria, Stephan Sampt:

At first I was skeptical about such a project, I did not know if its effect would be visible. I have extensive experience in stationary projects, where we cooperate for several months and then present the effect of the work. What are we going to do here? However, I saw the enthusiasm of young people, they had a desire to do something new. At the same time, they were happy that they would be the first, practically not moving from school, they would do something. As a teacher, of course, I remember that the goals of the partnership are part of the concept of improving the quality of school work. I read that there is a principle of mutual commitment, which means that both partners should equally involve their time and skills in the partnership. I thought that the students and teachers of each partner school would contribute as much as possible to the realization of jointly defined goals. Everyone will do it to the best of their abilities and taking into account any restrictions. Full access to all information on partnerships by both interested schools is also important. Traveling is not an option, especially at the beginning of cooperation. Virtual contact often has to be enough for us. That is why information and communication technologies (ICT) are extremely important during the implementation of the partnership - they allow us to communicate quickly and efficiently. I was surprised, but despite my abilities and knowledge, young people 
know technology better than teachers. By the way, we - the elders - can learn something more and observe. I am very pleased with the cooperation and recommend such solutions to other schools. Through multimedia, we connect once a week and discuss a selected topic related to ecology. This is obviously a social problem that bothers us, we help the partner school find a solution and they help us. In addition to the fact that we can expand language knowledge (we speak English), we also see ourselves through the webcam. At the end of the mini-project, we have fun together, hold an e-learning party. We play music, dance, play puns. It works out best for us. There is simply time for entertainment after hard work (S. Sampt, application of technology in an international school project, October 11, 2019).

The guardian of Polish youth, Jarosław Kinalski:

We are glad that we, as a school, could participate in such an innovative project. We see the same benefits: greater motivation to learn foreign languages and faster progress in learning, stimulation and development of imagination, a chance to make new acquaintances, practical application of information and communication technologies. It is primarily an openness to people representing other cultures, activities for a sustainable lifestyle, an increase in knowledge about school reality in a partner country. Despite the great skills demonstrated by students in this area, it is worth ensuring the support of an IT teacher. I took up this challenge and I'm happy. The technologies in such a project enable easy and quick communication with a partner from a distant country, motivate to work independently and raise competences in the field of using ICT, as well as affect the dissemination of information through a website. Thanks to this, students will learn about the new use of computers and the Internet, going beyond the basic methods of communication. Most of the meetings took place in this one room, because without a computer room in the project, we would never move forward. Therefore, it is worth determining from the very beginning what principles groups will work on. The advantage is that the partnership encourages students to apply the acquired knowledge about e-mail, internet forums, websites, etc. in practice. Our youth have started keeping electronic diaries, like their colleagues from Austria. And this is now a novelty among our students, and a cause of admiration in others. Thanks to the partnership, our students can acquire skills important in today's world, use and build an attitude of openness and actions. The partnership is part of our school's daily work, as it manages to focus on education 
The Role of Information Technology in Ecological Education in the Context of Cooperation...

(J. Kinalski, summary of the effects of the Polish school's cooperation with foreign schools, September 16, 2019).

The guardian of the Czech youth, Zdenek Mruzek:

The development of technology makes its mark on the functioning of students. Some time ago, I remember it was enough to be prepared at the level of computer literacy. Rapid changes in technology have forced the expansion of literacy into proficiency in the use of information and communication technologies. And dealing with computer help in problem situations caused interest in computational thinking. At the beginning of the development of IT education, it was enough for students and teachers to be able to use the office package and to communicate via the network. This basic preparation is not enough today. The purpose of equipping schools with the latest technology is to familiarize students with technology in times of its extremely rapid development and to prepare them for functioning in the information society. Why not use the possibilities of projects for this? If there are schools willing to cooperate without payment, if there are passionate teachers, then why not? Currently, computer and information technologies are integrated into almost every field. School graduates are expected to be well prepared to use these technologies. Thanks to such projects, our students have learned to think creatively and critically and are fluent in communicating and establishing relationships. It makes you happy. By doing projects, young people try to learn about their culture and customs. It opens to otherness and diversity. Thanks to such meetings, of course with an element of science, students develop skills in critical thinking and formulating their position (Z. Mruzek, new challenges in the digital school, September 3, 2019).

The main benefits of using new technologies in environmental education that the respondents mentioned were the low costs of carrying out this project and enabling meetings without the need to travel to other countries between participants. During the presented interview, the coordinators were very pleased with the results, because students, in addition to joint participation in ecological workshops, could compare the ecological awareness of people in their countries. They also highlighted the creativity of young people and their ideas. This exchange of thoughts inspires even better action for the benefit of our environment.

As part of the project, three teachers exchanged ideas on how to better use ICT tools at work during class. Everyone agrees that the project brought only benefits. The subjects concerned ecological activities, which, as it turned out in all three 
schools, despite the differences in state, are important and one should talk about ecology from an early age. Students eagerly connecting via multimedia, carried out joint ventures, exchanged ideas, and gathered the effects of their work together in an e-book. It turns out that projects do not have to be based on exchanges and trips. The project showed an innovative idea - through using technological equipment, it was possible to carry out several activities performed by young people who connected via the Internet. Each of the parties boasted their ecological activities, and at the same time improved their level of English. The most important element were low project costs. The teachers also emphasized that the project allowed them to learn new opportunities to use technology in education, watching young people. Polish students began to create their electronic diaries, like their foreign new friends.

\section{A Summary}

The issue of climate change is undoubtedly the current topic for discussion. Climate change is a fact and often the discussion about its causes hardly contributes to the real solution to the problem. A reliable debate on climate protection, as well as state fulfillment of international commitments undertaken in this area can contribute to the problem solution.

Social changes taking place in the world cause changes in lifestyle. Health care at home and the environment is becoming more and more important, and families are developing initiatives to raise children in an active respect of the environment and shape the ecological sensitivity from an early age. This ecological education has a great chance to change the existential attitude of a nation, which consists in treating life as an opportunity to experience pleasure (Bołoz, 1995, pp. 33-37).

One of the major problems of the modern world is the so-called "Ecological crisis," or a serious disturbance of the natural balance between man and his environment. This situation results from the disordered use and plundering of natural resources by human activities. Often, man does not realize that threatening his environment, he is threatening himself. Unfortunately, humankind, despite of the fact of being completely dependent on nature, unfavourably influences the existing balanced interaction between organisms and the environment. As a result, the entire ecology of the earth, thoroughly changes. Therefore, the human mission to the world can be described by three verbs: transform, serve and protect. Nature is not a completely self-renewing resource, therefore man cannot take a gladiatorial attitude towards it; we are not the only or the last generation, hence we cannot 
The Role of Information Technology in Ecological Education in the Context of Cooperation...

leave our land devastated. Today, ecology is a call to the proper attitude of man towards the world around him (Krawczyk, 1986, pp. 13-23).

Keep in mind that: "The basic idea is that students, who will come of age in the 21 st century, need to be taught different skills than those learned by students in the 20th century, and that the skills they learn should reflect the specific demands that will be placed upon them in a complex, competitive, knowledge-based, information-age, technology-driven economy and society" (Morze et al., 2016, p. 42). The essence of computer science is solving problems with the help of a computer. Students are struggling with problems and tasks from various subjects, and quite often a computer is the right tool to use. The problem is a situation where a student is to present a solution and steps leading to it, on the basis of what he knows but without any prior knowledge how to do it. The problem is generally of some difficulty, it is not a routine task. Schools should develop their students' IT competences more and more. The presented project of three schools from three different countries showed the importance of the described activities. Technology should increasingly be used during projects in order to enrich them.

It should be remembered that the use of technology can also take place during extracurricular activities, as well as projects that bring only benefits (such as shaping language and IT competences, as well as preparing students to international cooperation and developing their).

The use of technology in projects requires specific workload of coordinators and participants as a part of clearly defined activities, tasks and assigned roles. Using IT also helps in conducting the evaluation at the end of a project more efficiently. Thanks to such undertakings as the project described, schools will have the opportunity to train students' skills in working in international groups, prepare for independent search of information, also on the Internet, and improve the ability to select important information.

\section{References}

Bołoz, W. (1995). Etyczne uwarunkowania edukacji ekologicznej rodziny (Ethical conditions of ecological family education). In W. Bołoz (Ed.), Edukacja ekologiczna rodziny. Stan, możliwości, programy. Materiały z seminarium $w$ Lomiankach $k$. Warszawy 15.12.1994 (pp. 30-41). Akademia Teologii Katolickiej.

Brożek, J., Gawlik, R. (2011). Ekologia wyzwaniem XXI wieku (Ecology as a challenge of the 21st century). Instytut Obywatelski.

Dziekoński, S. (2002). Teologiczne podstawy wychowania ekologicznego w katechezie (Theological foundations of ecological education in catechesis). Ateneum Kaptańskie, 3, pp. 480-486.

IJREL.2020.6.2.09 p. 13/17 
Guzhelya, D., Kurilenko, V., \& Biryukova, Y. (2019). Distance technologies in teaching professional foreign languages for medical purposes. International Journal of Research in E-learning, 5(2), pp. 5-19.

Han, A., Wohn, K., \& Ahn, J. (2020). Towards new fashion design education: learning virtual prototyping using E-textiles. International Journal of Technology and Design Education, 1, 67-84.

Kowalak, A. (2009). Realizacja idei rozwoju zrównoważonego w podstawie programowej dla II i III etapu kształcenia (Implementation of the idea of sustainable development in the core curriculum for the second and third stage of education) Problemy Ekologii, 6, pp. 312-314.

Krawczyk, R. (1989). Stary Testament a ekologia (The Old Testament and ecology). Ateneum Kaptańskie, 1, pp. 13-23.

Krzysztofiak, K. (2009). Szkoła bezpieczna i przyjazna - cele nowego programu wychowawczego (Safe and friendly school - the goals of the new educational program). In K. Krzysztofiak (Ed.), Zarządzanie placówka oświatową. Poradnik nowoczesnego dyrektora (pp. 234-245). C. H. Beck.

Kulik, R. (2008). Ekologiczna perswazja, czyli jak zmieniać świat wpływając na ludzkie umysły (Ecological persuasion, or how to change the world affecting human minds). In M. Nakonieczny \& P. Migula (Eds.), Problemy środowiska i jego ochrony. Część 16 (pp. 179-186). Graf.

Łebkowski, W. (Ed.), (2008). Stownik terminów z zakresu bezpieczeństwa narodowego (Dictionary of terms from the field of national security), 6th edition. AON (National Defense University).

Magalhães, P., Ferreira, D., Cunha, J., \& Rosário, P., (2020). Online vs traditional homework: A systematic review on the benefits to students' performance. Computers and Education, 152, pp. 139-152.

Marek-Bieniasz, A. (2004). Świadomość ekologiczna - czym jest i jak się kształtuje? (Ecological awareness - what is it and how is it shaped?). In A. Misiołek (Ed.), Ksztaltowanie świadomości ekologicznej i edukacja na rzecz zrównoważonego rozwoju i ochrony środowiska (pp. 23-34). Wyższa Szkoła Ekonomii i Administracji.

Michalik, J. (2002). Chrześcijańska odpowiedzialność za ziemię. Refleksje o ekologii (Christian responsibility for the earth. Reflections on ecology). Ateneum Kapłańskie, 3, pp. 443-452.

Morze, N., Makhachashvili, R., \& Smyrnova-Trybulska, E., (2016). The roadmap of collaboration skills from programmed reaching to e-learning. International Journal of Research in E-learning, 2(1), pp. 41--56.

Papuziński, A. (1998). Życie, nauka, ekologia (Life, science, ecology). Wyższa Szkoła Pedagogiczna.

Peacocke, A. (1991). Teologia i nauki przyrodnicze (Theology and natural sciences). ZNAK.

Piontek, B. (2002). Koncepcja rozwoju zrównoważonego i trwatego Polski (The concept of sustainable and sustainable development of Poland). PWN.

Ruman, N. (2018). The role of ecological education and IT education in promoting sustainable development of a human being. International Journal of Research in E-learning, 4(2), pp. 107-123.

Ruman, N., Kubiak, P., (2018). Information Technology in the context of pedagogical innovation for sustainable development. Examples of activities in Poland and Austria. In E. SmyrnovaTrybulska (Ed.) E-learning and smart learning environment for the preparation of new generation specialists. Seria on E-learning. Vol. 10 (pp. 311-326). Studio Noa for University of Silesia..

Simonova, I., Ustiugova, T., \& Yakovleva, O., (2017). The impact of online services on developing students' media competence. International Journal of Research in E-learning, 3(2), pp. 35-48.

Skubała, P., Smyrnova-Trybulska, E., (2014). E-learning as an effective modern method of building a sustainable society. International Journal of Continuing Engineering Education and LifeLong Learning, 24(1), pp. 62-76. 
The Role of Information Technology in Ecological Education in the Context of Cooperation...

Smyrnova-Trybulska, E., Noskova, T., Pavlova, T., Yakovleva, O., \& Morze, N. (2016). New educational strategies in contemporary digital environment. International Journal of Continuing Engineering Education and Life-Long Learning, 26(1), pp. 6-24.

Sobczyk, W. (2003). Teoretyczna i eksperymentalna analiza edukacji ekologicznej młodzieży. Wydawnictwo Naukowe Akademii Pedagogicznej.

Sztumski, W. (2006). The idea of sustainable development and possibility of its realization, Problemy Ekorozwoju, 2(1), pp. 71-76.

Tavernise, A., Bertacchini, F. (2017). Designing virtual worlds for learning history: the case study of netconnect project. In. A. Tavernise \& F. Bertacchini (Eds.) Serious games and edutainment applications (pp. 273-285). Springer International Publishing.

Zacher, L. (1991). Bezpieczeństwo ekologiczne - wymiary polityczne, międzynarodowe i globalne (Ecological security - political, international and global dimensions). In Z. Pietraś \& M. Pietraś (Eds.) Międzynarodowe bezpieczeństwo ekologiczne (pp. 93-102). UMCS.

Natalia Maria Ruman, Martha Finger, Stephan Sampt, Zdenek Mruzek

\section{Rola technologii informacyjnej w edukacji ekologicznej w kontekście współpracy szkół średnich z Polski, Austrii i Czech}

Streszczenie

Współczesne problemy ekologiczne świata mogą być badane nie tylko jako sondaż wiedzy, opinii i postaw, ale także jako projekt mający na celu stymulowanie społeczeństwa od najmłodszych lat do odpowiedzialności za środowisko, zwiększenie indywidualnej świadomości ekologicznej. Artykuł stanowi podsumowanie prac przeprowadzonych w ramach projektu trzech współpracujących szkół reprezentujących Polskę, Austrię i Czechy. Celem projektu było rozważenie znaczenia ekologii na poziomie szkół średnich w wybranych krajach, uczestniczących w tym projekcie oraz wykorzystanie technologii do realizacji tego projektu. Międzynarodowi koordynatorzy projektów przeprowadzali wywiady. Pytania dotyczyły: zastosowania technologii w międzynarodowym projekcie szkolnym, podsumowania efektów współpracy polskiej szkoły ze szkołami zagranicznymi i nowych wyzwań w cyfrowej szkole. Przeprowadzono również badania jakościowe. Projekt został również przeanalizowany pod kątem uwzględnionych działań i zaprezentowano efekty. Główną kwestią poruszoną w projekcie jest ochrona środowiska i ekologia. Zwrócono uwagę na problemy Ziemi, jako wspólnego domu wszystkich ludzi. Podkreślono także dialog o współpracy w dziedzinie ekologii. Prawdziwa ochrona środowiska, jak pokazują opisane w artykule działania uczniów z trzech krajów, to nowy styl edukacji, nowe podejście do ekologii, co jest wezwaniem do właściwej relacji człowieka z otaczającym go światem.

S łow a k lu c z ow e: ochrona środowiska, zrównoważony rozwój, innowacje edukacyjne, ekologia, technologia informacyjna 
Natalia Maria Ruman, Martha Finger, Stephan Sampt, Zdenek Mruzek

\title{
Роль информационных технологий в экологическом образовании в контексте сотрудничества между вузами Польши, Австрии и Чехии
}

\author{
А н н о т а ци я
}

Современные экологические проблемы мира можно изучать не только как обзор знаний, мнений и взглядов, но и как проект, направленный на стимулирование общества с раннего возраста к ответственности за окружающую среду, повышение индивидуальной экологической осведомленности. Статья представляет собой резюме работы, выполненной в рамках проекта трех сотрудничающих школ, представляющих Польшу, Австрию и Чешскую Республику. Целью проекта было рассмотреть важность экологии на уровне средних школ в отдельных странах, участвующих в этом проекте, и использование технологий для реализации этого проекта.

С международными координаторами проекта были проведены собеседования. Были затронуты следующие вопросы: применение технологий в международном школьном проекте, краткое изложение результатов сотрудничества польской школы с иностранными школами и новые вызовы в цифровой школе. Качественное исследование было проведено. Проект также был проанализирован с точки зрения деятельности, включенной в него, и были представлены результаты.

Основными вопросами, затронутыми в проекте, являются охрана окружающей среды и экология. Внимание было уделено проблемам Земли, общему дому всех людей. Была также подчеркнута роль образования в формировании возможного международного диалога о сотрудничестве в области экологии. Реальная защита окружающей среды, о чем свидетельствует деятельность студентов из трех стран, описанная в статье, - это новый стиль образования, новый подход к экологии, который является призывом к надлежащим отношениям человека с окружающим его миром.

Ключевые слова: охрана окружающей среды, устойчивое развитие, образовательные инновации, экология, информационные технологии

Natalia Maria Ruman, Martha Finger, Stephan Sampt, Zdenek Mruzek

\section{El papel de la tecnología de la información en la educación ecológica en el contexto de la cooperación entre escuelas secundarias de Polonia, Austria y la República Checa}

Resumen

Los problemas ecológicos contemporáneos del mundo pueden estudiarse no solo como una encuesta de conocimiento, opiniones y actitudes, sino también como un proyecto destinado a estimular a la sociedad desde una edad temprana a la responsabilidad por el medio ambiente, aumentando la conciencia ecológica individual. El artículo es un resumen del trabajo realizado en el marco del 
The Role of Information Technology in Ecological Education in the Context of Cooperation...

proyecto de tres escuelas cooperantes que representan a Polonia, Austria y la República Checa. El objetivo del proyecto era considerar la importancia de la ecología a nivel de escuelas secundarias en países seleccionados que participan en este proyecto y el uso de tecnología para implementarlo.

Se entrevistó a coordinadores de proyectos internacionales. Las preguntas se referían a: aplicación de tecnología en un proyecto escolar internacional, resumen de los efectos de la cooperación de la escuela polaca con escuelas extranjeras y nuevos desafíos en la escuela digital. Se realizó un estudio cualitativo. El proyecto también se analizó en términos de actividades incluidas en él, y se presentaron los efectos.

Los principales problemas planteados en el proyecto son la protección del medio ambiente y la ecología. Se prestó atención a los problemas de la Tierra, el hogar común de todas las personas. También se hizo hincapié en el papel de la educación en la configuración de un posible diálogo internacional sobre cooperación en el campo de la ecología. La verdadera protección del medio ambiente, como lo demuestran las actividades de los estudiantes de los tres países descritos en el artículo, es un nuevo estilo de educación, un nuevo enfoque de la ecología, que es un llamado a la relación adecuada del hombre con el mundo que lo rodea.

P a labras clave: protección del medio ambiente, desarrollo sostenible, innovaciones educativas, ecología, tecnología de la información 
IJREL.2020.6.2.07 p. 18/18 